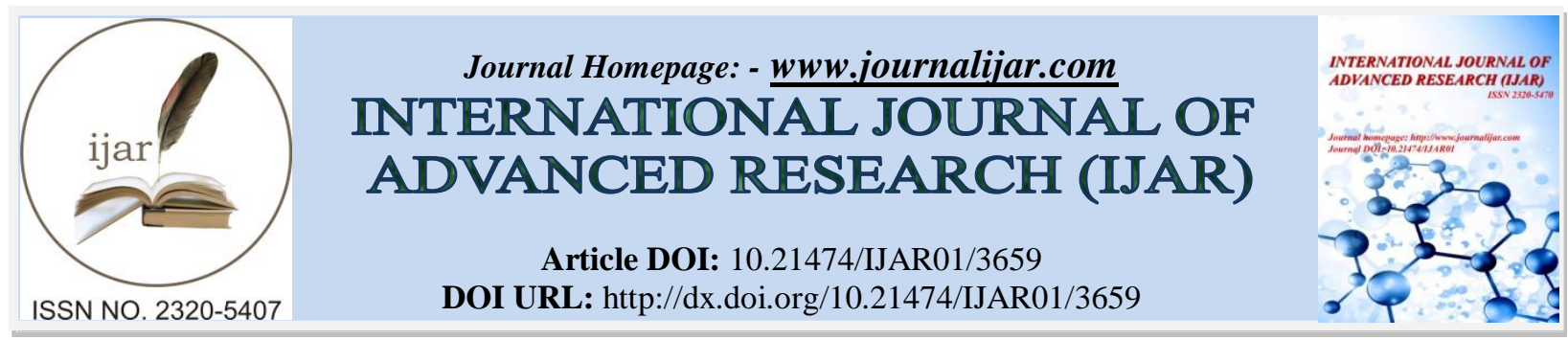

RESEARCH ARTICLE

\title{
SCREENING OF INFERTILE FEMALES FOR VAGINAL CANDIDIASIS
}

${ }^{*}$ Ankana Chakraborty ${ }^{1}$, B. A. Dalal ${ }^{2}$, S. R. Shah ${ }^{3}$, C. S. Deshmukh ${ }^{4}$ and K. K. Lahiri ${ }^{5}$.

1. $3^{\text {rd }}$ Year PG Resident, Dept. of Microbiology, Bharati Vidyapeeth Deemed University and Medical College, Pune.

2. Associate Professor, Dept. of Microbiology, Bharati Vidyapeeth Deemed University and Medical College, Pune.

3. Tutor, Dept. of Microbiology, Bharati Vidyapeeth Deemed University and Medical College, Pune.

4. Faculty, Dept. of Obstetrics and Gynaecology, Bharati Vidyapeeth Deemed University and Medical College, Pune.

5. Professor and H.O.D., Dept. of Microbiology, Bharati Vidyapeeth Deemed University and Medical College, Pune.

\section{Manuscript Info}

Manuscript History

Received: 10 January 2017

Final Accepted: 06 February 2017

Published: March 2017

Key words:-

Infertility, Lower genital tract infection,

Candida spp., Fluconazole resistance

\section{Abstract}

Introduction: Infertility is a major public health problem across worldwide and in India. As per WHO, 60 to 80 million couples worldwide currently suffer from infertility. The role of female reproductive tract infection, symptomatic or asymptomatic, is well recognized. Studies reveal that Candida albicans have spermimmobilizing property which might lead to infertility. Keeping this in mind the present study was done. Aim: To screen infertile females for vaginal candidiasis. Material \& Methods: 100 infertile women were screened for vaginal candidiasis. High Vaginal swab collected from them were processed for fungal culture using conventional methods. Anti-Fungal susceptibility testing was done for all the isolates of Candida spp. as per guidelines. Results: $17 \%$ of the patients suffered from vaginal candidiasis. Candida albicans followed by Candida tropicalis were the most common isolates. None of the isolates were resistant to Amphotericin B and Nystatin while maximum resistance was shown for Fluconazole. Conclusion: There was more predominance of non albicans Candida in the study thereby showing a change in causative agent of vaginal candidiasis. Moreover since studies show sperm-immobilising property of Candida spp., infertile women should be routinely screened for vaginal candidiasis.

Copy Right, IJAR, 2017,. All rights reserved.

\section{Introduction:-}

Infertility is a major public health problem across worldwide and in India. World Health Organization (WHO) defines infertility as "the inability of a sexually active, non-contracepting couple to achieve pregnancy in one year" (WHO laboratory manual for the examination and processing of human semen, 2010). As per WHO, 60 to 80 million couples worldwide currently suffer from infertility (Infecundity, infertility and childlessness in developing countries. Demographic and Health Surveys (DHS) Comparative reports No. 9, 2004). 
Besides other causes of female infertility, the role of female reproductive tract infection is well recognized. Infections may be in the form of Pelvic Inflammatory diseases (PID) or lower genital tract infection, either of which can be asymptomatic or symptomatic. These infections need to be diagnosed and treated properly to set the patient free from the grasp of infertility. Candida infection plays an important role in this regard. As per studies, Candida albicans have sperm-immobilizing property (Harpreet \& Vijay, 2015; and Tian et al., 2007). When the spermimmobilizing strains of Candida albicans were intravaginally inoculated into female mice, it showed $100 \%$ decrease in fertility in all groups as compared with control mice. Moreover, since no clinical or histopathological changes were observed in the reproductive organs, colonization of the genital tract with sperm-impairing micro-organisms could be the reason behind female infertility (Harpreet \& Vijay, 2015). As per Mathur et al.(Mathur et al.,1980), patients with chronic vaginal candidiasis of at least 5 years duration showed high titres of auto-antibodies to ovary which may be due to the presence of one or more cross-reactive antigens on ovarian follicle and Candida spp. Thus chronic vaginal candidiasis may be associated with decreased ovarian function, thereby affecting the fertility outcome.

In view of this, our study was carried out to evaluate vaginal candidiasis in infertile females.

\section{Material and Methods:-}

It was a cross sectional study carried out for a period of one year (2014-2015) in a Tertiary care teaching hospital in Western India. The study was approved by the institutional ethics committee. A total of 100 married reproductive age group females (18 - 49 years) attending infertility clinic, with the exception of those receiving antibiotic and antifungal therapy in previous one month, were included in the study. A questionnaire covering demographic data, menstrual history, contraceptive use, recent antibiotic use, medical history \& history of vaginitis and infertility was completed for each of the participants. After taking consent, High Vaginal swab (HVS) was collected under speculum examination using sterile swab.

$\mathrm{KOH}(10 \%)$ mount was prepared to detect presence of Candida. A gram stained smear was examined for the composition of bacterial morphology and presence of yeasts and leukocytes. All the specimens were inoculated on Sabouraud Dextrose Agar (SDA) which was incubated at $37^{\circ} \mathrm{C}$. In case of growth, discrete colonies were picked and processed further for identification using conventional methods like Germ Tube Test (GTT), Chrome agar, Corn Meal Morphology.

Antifungal susceptibility testing was done by disc diffusion method as per guidelines (NCCLS May 2004). Antifungal agents used for susceptibility testing (HIMEDIA Hexa Antimyco-01) are mentioned in Table 1. Antifungal susceptibility pattern was interpreted as per NCCLS (NCCLS May 2004) and manufacturer's guidelines.

Table 1:- Antifungals used for susceptibility testing

\begin{tabular}{|c|c|c|}
\hline Sr. No. & Antifungal agent & Dose \\
\hline 1. & Fluconazole & $25 \mu \mathrm{g}$ \\
\hline 2. & Ketoconazole & $10 \mu \mathrm{g}$ \\
\hline 3. & Itraconazole & $10 \mu \mathrm{g}$ \\
\hline 4. & Nystatin & 100 units \\
\hline 5. & Amphotericin B & 100 units \\
\hline 6. & Clotrimazole & $10 \mu \mathrm{g}$ \\
\hline
\end{tabular}

\section{Results:-}

The various findings of our study were analysed as follows. Out of 100 patients, Candida spp. was isolated from 17 of them. Among the fungal isolates of our study, Candida albicans (35.3\%) was the most predominant fungal isolate followed by Candida tropicalis (29.4\%). The distribution of various Candida spp. was as shown in Fig 1. The resistance pattern of the isolates was as shown in Fig 2. 


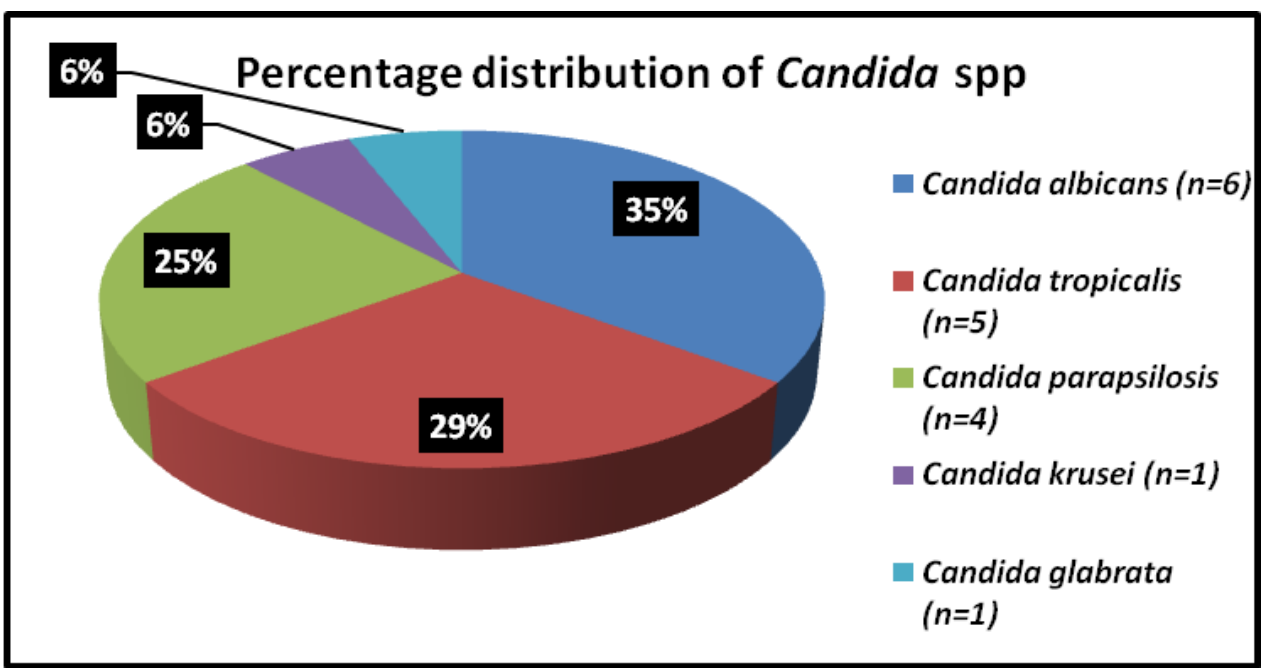

Fig 1:- \% distribution of Candida spp

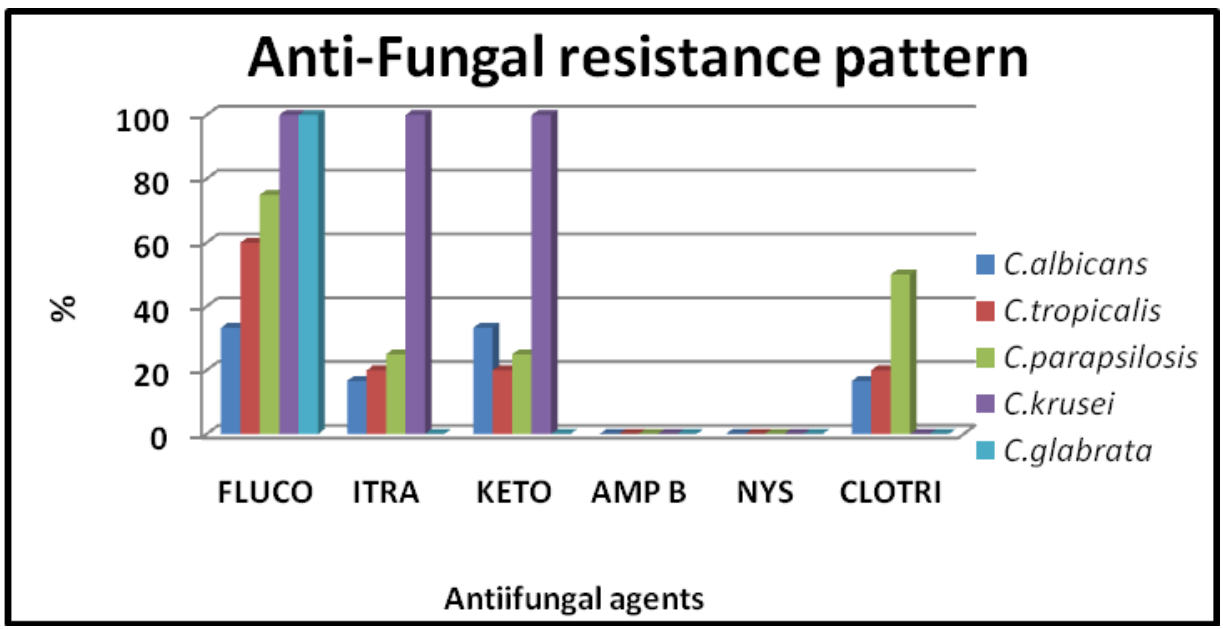

Fig 2:- Anti-fungal resistance pattern

\section{Discussion:-}

In our study, Candida spp was isolated from 17\% of the cases which is bit higher than that reported by Rodriguez et al. (Rodriguez et al., 2001). Ghiasi et al. (Ghiasi et al., 2014) and Gupta et al. (Gupta et al., 2014) had shown prevalence of Candida spp. as low as $1.4 \%$ and 5.9\% respectively. Unlike our study, other studies showed prevalence of Candida spp. as high as 22\%, 25\%, 30.8\% and 43.5\% (Saleh, 2010; Okonofua et al., 1995; Paul et al., 2011; Ogiogwa et al., 2012).

Candida albicans (35.3\%) was the most common fungal isolate which is similar to results of the study done by Verghese et al. (Verghese et al., 2001). In our study, Candida tropicalis (29.4\%) was the second most predominant fungal isolate, unlike Verghese et al. (Verghese et al., 2001) where the second most common isolate was Candida glabrata. Candida krusei constituted $5.9 \%$ of the fungal isolates in our study which is similar to Verghese et al. (Verghese et al., 2001).

Broadly speaking, none of Candida spp. in our study showed resistance to Amphotericin B and Nystatin. Maximum resistance was shown for Fluconazole followed by Ketoconazole, Itraconazole and Clotrimazole. Unlike our study, Fluconazole was the drug of choice for vaginal candidiasis in another study (Khan \& Rakshanda, 2010). As per Gandhi et al. (Gandhi et al.,2015), antifungal susceptibility pattern showed that Candida isolates were more sensitive to Amphotericin -B (98.36\%) and Nystatin (100\%), compared to that of Clotrimazole $(79.5 \%)$ and Azoles like Fluconazole (79\%), Itraconazole (52\%) and Ketoconazole (76\%). As per Verghese et al. (Verghese et al.,2001), 
16.7\% Candida strains showed resistance to Fluconazole, $45.23 \%$ of the strains showed resistance to Itraconazole, 9.5\% strains showed resistance to Nystatin while there was no resistance to Amphotericin B.

A comparative analysis of the resistance pattern of Candida species isolated in our study, for Fluconazole, Itraconazole, Ketoconazole and Clotrimazole are given Table 2-5 respectively.

Table 2:- Comparison of Resistance pattern (\%) for Fluconazole

\begin{tabular}{|l|l|l|l|l|l|l|}
\hline Candida species & $\begin{array}{l}\text { Our } \\
\text { study }\end{array}$ & $\begin{array}{l}\text { Gandhi et al., } \\
\mathbf{2 0 1 5}\end{array}$ & $\begin{array}{l}\text { Adeshji et al., } \\
\mathbf{2 0 1 0}\end{array}$ & $\begin{array}{l}\text { Sachin } \\
\text { Santosh, 2013 }\end{array}$ & $\begin{array}{l}\text { Salehei et al., } \\
\mathbf{2 0 1 2}\end{array}$ \\
\hline C. albicans & 33.33 & 17 & 84.6 & - & 81.13 \\
\hline C. tropicalis & 60 & 17 & 66.7 & 29.5 & 100 \\
\hline C. parapsilosis & 75 & 0 & - & 10 & - & 100 \\
\hline C. krusei & 100 & 33 & 100 & 18.8 & 100 \\
\hline C. glabrata & 100 & 15.70 & 50 & 27.3 & \\
\hline
\end{tabular}

Table 3:- Comparison of Resistance pattern (\%) for Itraconazole

\begin{tabular}{|l|l|l|l|l|}
\hline Candida species & $\begin{array}{l}\text { Our } \\
\text { study }\end{array}$ & Gandhi et al., 2015 & $\begin{array}{l}\text { Sachin \& Santosh, } \\
\mathbf{2 0 1 3}\end{array}$ & Salehei et al., 2012 \\
\hline C. albicans & 16.67 & 13.50 & - & 15.09 \\
\hline C. tropicalis & 20 & 8.34 & 9.8 & 0 \\
\hline C. parapsilosis & 25 & 16.66 & 10 & - \\
\hline C. krusei & 100 & 33.33 & 21.9 & 0 \\
\hline C. glabrata & 0 & 15.78 & 12.7 & 0 \\
\hline
\end{tabular}

Table 4:- Comparison of Resistance pattern (\%) for Ketoconazole

\begin{tabular}{|l|l|l|l|l|}
\hline Candida species & $\begin{array}{l}\text { Our } \\
\text { study }\end{array}$ & Gandhi et al., 2015 & $\begin{array}{l}\text { Sachin \& Santosh, } \\
\mathbf{2 0 1 3}\end{array}$ & Salehei et al., 2012 \\
\hline C. albicans & 33.33 & 11 & - & 43.39 \\
\hline C. tropicalis & 20 & 17 & 39.4 & 25 \\
\hline C. parapsilosis & 25 & 0 & 10 & - \\
\hline C. krusei & 100 & 33.5 & 25 & 0 \\
\hline C. glabrata & 0 & 5 & 13.7 & 12.25 \\
\hline
\end{tabular}

Table 5:- Comparison of Resistance pattern (\%) for Clotrimazole

\begin{tabular}{|c|c|c|c|c|}
\hline Candida species & $\begin{array}{l}\text { Our } \\
\text { study }\end{array}$ & Gandhi et al., 2015 & $\begin{array}{l}\text { Ajitha \& Maimoona, } \\
2014\end{array}$ & Salehei et al., 2012 \\
\hline C. albicans & 16.67 & 9 & 20 & 1.88 \\
\hline C. tropicalis & 20 & 17 & 45.5 & 50 \\
\hline C. parapsilosis & 50 & 0 & 50 & - \\
\hline C. krusei & 0 & 67 & - & 0 \\
\hline C. glabrata & 0 & 5 & 33.3 & 0 \\
\hline
\end{tabular}

\section{Conclusion:-}

There was more predominance of non albicans Candida in our study thereby showing a change in causative agent of vaginal candidiasis. Candida spp. isolated in our study were least resistant to Amphotericin B and Nystatin while showed maximum resistance to Fluconazole. As per reports from other studies, Candida albicans plays an important role in female infertility; hence infertile females should be routinely screened for vaginal candidiasis.

\section{Acknowledgement:-}

We are thankful to all faculties and staff of Microbiology department and Obs. \& Gynae. Department, for their continuous support in performing this study.

\section{Copyright:-}

Only those articles should be submitted that have not been published in past anywhere (except in the form of an abstract or as part of a published lecture, or thesis) or have not been under consideration for publication anywhere. If the article is accepted for publication, author agrees to automatically handover all the copyrights to publisher. 


\section{References:-}

1. Adesiji Y.O., N. Ndukwe, B. M. Okanlawon. C Isolation and Antifungal Sensitivity to Candida Isolates in Young Females. Central Europen Journal of Medicine,2011;6(2):172-76.

2. Ajitha Reddy, Maimoona Mustafa. Phenotypic identification of candida species and their susceptibility profile in patients with genitourinary candidiasis International Journal of Advanced Research (2014), 2(12):76-84.

3. F E Okonofua, K A Ako-Nai, M D Dighitoghi. Lower genital tract infections in infertile Nigerian women compared with controls.Genitourin Med 1995;71:163-168.

4. Gandhi Twinkle N, Manish G. Patel, Mannu R. Jain. Antifungal Susceptibility of Candida against Six Antifungal Drugs by Disk Diffusion Method Isolated from Vulvovaginal Candidiasis. Int J Cur Res Rev,2015;7(11):20-25.

5. Ghiasi Mahdieh, Hoda Fazaeli, Naser Kalhor, Mohsen Sheykh-Hasan, Reza Tabatabaei-Qomi.Assessing the prevalence of bacterial vaginosis among infertile women of Qom city. IRAN. J. MICROBIOL.,2014;6(6):404408

6. Gupta Sapna, Goyal Ankur, Singh Saroj, Agrawal BM. Outcome of routine microbiological screening for lower genital tract infections in symptomatic non-pregnant females complaining infertility. IOSR Journal of Dental and Medical Sciences (2014);13 (1), Ver. III: 26-29.

7. Harpreet Vander and Vijay Prabha. Evaluation of fertility outcome as a consequence of intravaginal inoculation with sperm-impairing microorganisms in a mouse model. Journal of Medical Microbiology (2015), 64, 344-347 DOI 10.1099/jmm.0.000036.

8. Infecundity, infertility, and childlessness in developing countries. Demographic and Health Surveys (DHS) Comparative reports No. 9[Internet]. World Health Organization. [cited 11 October 2016]. Available from: http://www.who.int/reproductivehealth/topics/infertility/definitions/en/

9. Khan Fouzia, Rakhshanda Baqai. In vitro antifungal sensitivity of fluconazole, Clotrimazole and nystatin against vaginal candidiasis in females of childbearing age. J Ayub Med Coll Abbottabad 2010;22(4):197-200

10. Mathur S, Melchers JT 3rd, Ades EW, Williamson HO, Fudenberg HH. Antiovarian and anti-lymphocyte antibodies in patients with chronic vaginal candidiasis. J Reprod Immunol. 1980 Dec;2(5):247-62.

11. National Committee on Clinical Laboratory Standards (NCCLS) document M44-A. Method for Antifungal Disk Diffusion Susceptibility Testing of Yeasts; Approved Guideline. May 2004; Vol. 24: No. 15

12. Ogiogwa I. O. Motayo B. O., Nwanze J.C., Onoh C.C., Adeniji F.O., Okerentugba PO, Okonko I.O.Antibiogram and Occurrence Rate Of Bacteria Recovered From Patients Attending A FERTILITY Clinic In ABEOKUTA, Nigeria. Nature and Science, 2012;10(4):27-31.

13. Paul C. Adamson, Karl Krupp, Alexandra H. Freeman, Jeffrey D. Klausner, Arthur L. Reingold,Purnima Madhivanan.Prevalence \& Correlates of Primary Infertility in Mysore, India. Indian J Med Res (2011);134: 440-446.

14. Rodríguez R, Hernández R, Fuster F, Torres A, Prieto P, Alberto J.Genital infection and infertility. Enferm Infecc Microbiol Clin. 2001 Jun-Jul;19(6):261-6.

15. Sachin C Deorukhkar, Santosh Saini. Vulvovaginal Candidiasis due to non albicans Candida: its species distribution and antifungal susceptibility profile Int. J. Curr. Microbiol App. Sci (2013) 2(12): X-xx

16. Saleh W H. Prevalence of bacterial infection and their sensitivity in patients undergoing an infertility eval. Al Kindy Col Med J 2010 ; Vol .6 . No. (1)

17. Salehei Zahra, Zahra Seifi, Ali Zarei, Mahmoudabadi A.Sensitivity of Vaginal Isolates of Candida to Eight Antifungal Drugs Isolated From Ahvaz, Iran. Jundishapur J Microbiology.2012;5(4):574-577.

18. Tian YH , Xiong JW, Hu L, Huang DH, Xiong CL.Candida albicans and filtrates interfere with human spermatozoal motility and alter the ultrastructure of spermatozoa: an in vitro study. Int J Androl. 2007 Oct;30(5):421-9. Epub 2007 Feb 12.

19. Verghese S , Padmaja P, Asha M, Elizabeth SJ, Anitha A, Kundavi KM, Jayanthi N, Varma T. Prevalence, species distribution and antifungal sensitivity of vaginal yeasts in infertile women.Indian J Pathol Microbiol. $2001 \mathrm{Jul} ; 44(3): 313-4$.

20. WHO laboratory manual for the examination and processing of human semen [Internet]. World Health $\begin{array}{lllll}\text { Organization. } & \text { [cited } & 11 & \text { October } & \text { 2016]. }\end{array}$ from:http://www.who.int/reproductivehealth/topics/infertility/definitions/en/ 